\title{
Codifying Social Determinants of Health: a Gap in the ICD-10-CM
}

\author{
Zachary G. Jacobs, MD® \\ Division of Hospital Medicine, Oregon Health \& Science University, Portland, OR, USA.
}

J Gen Intern Med 36(10):3205-7

DOI: $10.1007 / \mathrm{s} 11606-021-06742-4$

(c) Society of General Internal Medicine 2021

I f you have ever found yourself experiencing R45.4 (irritability and anger) in response to scrolling through endless rows of diagnosis codes, you are not alone: navigating medical billing and coding can be equal parts frustrating and mystifying. The sheer number of International Classification of Diseases, Clinical Modification (ICD-CM) diagnosis codes-which approaches 70,000 as of the tenth revision ${ }^{1}$ — can feel overwhelming. Some codes, like V91.07 (burn due to water-skis on fire), are so absurdly specific it is hard to imagine them ever being used in clinical practice. Meanwhile, social determinants of health (SDOH), which are major contributors to quality of life and disparities in health outcomes, are glaringly underrepresented in this plethoric catalog.

The first comprehensive system for classification of diseases was adopted in 1983, originally known as the International List of Causes of Death. ${ }^{2}$ Over time, it was transformed by the World Health Organization (WHO) into the ICD, which contains a list of codes defining various diseases and healthrelated conditions. Currently in its tenth revision (ICD-10), an eleventh edition is set for release in 2022. Further modifications are made each year by the National Center for Health Statistics (NCHS), the federal agency responsible for adapting the system for clinical practice in the United States.

One of the major criticisms of the ICD system, particularly in its tenth revision, is that it is far too complex to be practical. This is perhaps best illustrated by any number of amusing diagnosis codes available for clinical use. For example, ornithologists and herpetologists alike can rest assured that their workplace-related injuries will be accounted for, with such codes as W61.5 (contact with goose); W61.11 (bitten by macaw); W59.22 (struck by turtle); and T63.81 (toxic effect of venomous frog). For extreme thrill seekers, codes for sports-related injuries are also available, like V97.33 (sucked

Received December 9, 2020

Accepted March 17, 2021

Published online March 29, 2021 into jet engine); X52 (prolonged stay in weightless environment); and V94.810 (civilian watercraft involved in water transport accident with military watercraft). And for those who maintain somewhat tamer hobbies, there is always Y93.D (activities involving arts and handcrafts).

While the above examples are laughable, if nothing else, we can take solace in the fact that the ICD-10-CM classification system offers a degree of specificity that allows us to fully represent the diversity of illnesses and conditions impacting our patients, which makes the undervaluing of SDOH among this comprehensive list even more profound. The WHO defines $\mathrm{SDOH}$ as "the conditions in which people are born, grow, live, work, and age". ${ }^{3}$ They are the non-medical factors that influence both quality and quantity of life, such as finance, nutritious food, safe work and living environments, sustainable housing, transportation, education, community resources, and social support. There is a subsection within the ICD-10$\mathrm{CM}$ known as $\mathrm{Z}$ codes, which represent various reasons for healthcare encounters, with categories Z55-Z65 used to designate "health hazards related to socioeconomic and psychosocial circumstances". ${ }^{1}$ This is where codes for SDOH are currently housed; however, accounting for less than $1 \%$ of the nearly 70,000 codes in the ICD-10-CM, they are grossly underrepresented proportional to their significant impact on health outcomes.

SDOH have pervasive effects on health and wellbeing. ${ }^{3}$ In the United States, more than 1 in 10 live in poverty. The same number lack health insurance and an even greater proportion are underinsured. In 2016, 12.3\% of Americans suffered from inadequate access to food; of those in low-income households, nearly a third were food insecure. Chronic houselessness affects more than half a million annually, while millions of households are severely cost burdened. These social determinants, among numerous others, have significant adverse impacts on health, both directly and indirectly. In fact, while the provision of medical care makes up the vast majority of healthcare expenditures in the United States, it is estimated to contribute less than $20 \%$ to the modifiable impact on health outcomes; meanwhile, social and economic factors, personal behaviors, and physical environment collectively account for more than $80 \% .{ }^{4}$ Moreover, $\mathrm{SDOH}$ are a major contributor to health disparities, with certain groups suffering from disproportionately higher rates of social and economic burdens. This is a consequence of generations of systemic racism, exclusion, and limitations in access and opportunities based on race and 
ethnicity, sexual orientation, gender identity, socioeconomic status, physical and mental ability, and even geography. ${ }^{5}$ Addressing SDOH would lead to a more equitable provision of healthcare in our country; the first step in doing so involves recognizing and cataloguing the extent of the problem.

$\mathrm{SDOH}$ are one of the five core measures of the Healthy People 2030 initiative, a nationwide health promotion and disease prevention program. ${ }^{3}$ Yet they are all but missing from the ICD-10-CM, the global standard for cataloging statistics on morbidity and mortality and the system responsible for reimbursement and resource allocation of nearly three-quarters of the world's healthcare expenditures. ${ }^{2}$ Increasing the number and granularity of diagnosis codes would not only allow for better identification and tracking of inequities and outcomes relating to $\mathrm{SDOH}$, it would also improve our ability to address these issues via referrals to appropriate social/governmental services. Many of the existing codes for $\mathrm{SDOH}$ are far too generic, such as Z59.8 (low income), which encompasses a wide array of financial issues, each requiring a distinct solution. Others, like Z59.9 (living rough), are simply unhelpful. Several organizations - including the American Medical Association, UnitedHealthcare, and the American Hospital Association - have petitioned to expand $\mathrm{Z}$ codes to capture a broader range of SDOH and with greater specificity (Table 1). ${ }^{6}$

But the problem goes beyond just a paucity of codes: due to lack of standardized screening tools as well as inconsistent reimbursement, $\mathrm{Z}$ codes are also rarely used. A 2017 study of nearly 34 million Medicare Fee-for-Service beneficiaries found that only $1.4 \%$ had claims using $\mathrm{Z}$ codes. ${ }^{7}$ When you consider the breadth of issues these codes are meant to capture, it is clear they are not only lacking in abundance and specificity but also being vastly underutilized. Fortunately, $\mathrm{Z}$ codes can be assigned using documentation from any clinician on the healthcare team, or even based solely on patients' self-reported social needs. ${ }^{1}$ This makes $\mathrm{Z}$ codes more accessible than typical ICD codes, but we need to implement standardized assessment tools and train our interprofessional healthcare teams to use them. Moreover, clear reimbursement guidelines must be established to ensure consistent utilization.

In a classification system so extensive that turtle-related injuries and combustible water-skis have found a home, there is no excuse for $\mathrm{SDOH}$ - the largest contributor to modifiable health outcomes - to be delegated to a tiny, underutilized subsection of an otherwise massive catalog. If the concern is size and complexity, then perhaps rather than codifying injuries from every subspecies of exotic bird and reptile, we should instead use that space for the social factors that are disproportionately and unjustly impacting the health of minorities and vulnerable groups. While the ICD-11 has already been finalized, ICD-CM is updated annually, so there is ample opportunity to make changes - if we lend support to organizations spearheading them. And although increasing the quantity, granularity, and utilization of $\mathrm{Z}$ codes for $\mathrm{SDOH}$ will not ultimately fix a healthcare system rife with inequity, it is a
Table 1 Selection of Existing and Proposed Z Codes for Various Categories of Social Determinants of Health

\begin{tabular}{|c|c|c|}
\hline $\begin{array}{l}\text { ICD-10-CM Z } \\
\text { code categories }\end{array}$ & $\begin{array}{l}\text { Sample of existing } \mathrm{Z} \\
\text { codes }\end{array}$ & Proposed $Z$ codes $*$ \\
\hline $\begin{array}{l}\text { Z55 Education } \\
\text { and literacy }\end{array}$ & $\begin{array}{l}\text { Illiteracy/low-level } \\
\text { literacy } \\
\text { School } \\
\text { unavailable/unattainable } \\
\text { Underachievement in } \\
\text { school }\end{array}$ & $\begin{array}{l}\text { Less than a high school } \\
\text { degree } \\
\text { Limited English } \\
\text { proficiency } \\
\text { Low health literacy }\end{array}$ \\
\hline $\begin{array}{l}\text { Z56 } \\
\text { Employment }\end{array}$ & $\begin{array}{l}\text { Unemployment } \\
\text { Threat of job loss } \\
\text { Stressful work schedule }\end{array}$ & $\begin{array}{l}\text { Unemployed, seeking } \\
\text { work } \\
\text { Unemployed, not } \\
\text { seeking work } \\
\text { Employed part time or } \\
\text { temporary } \\
\text { On permanent } \\
\text { disability }\end{array}$ \\
\hline $\begin{array}{l}\text { Z57 } \\
\text { Occupational } \\
\text { exposures } \\
\text { Z59 Housing } \\
\text { and economic }\end{array}$ & $\begin{array}{l}\text { Noise } \\
\text { Tobacco smoke } \\
\text { Toxic agents } \\
\text { Homelessness } \\
\text { Inadequate housing } \\
\text { Discord with } \\
\text { neighbors/landlord } \\
\text { Residential institution } \\
\text { problems } \\
\text { Lack of adequate } \\
\text { food/water } \\
\text { Inadequate welfare } \\
\text { support } \\
\text { Extreme poverty } \\
\text { Low income } \\
\text { Insufficient welfare } \\
\text { support }\end{array}$ & $\begin{array}{l}\text { Ergonomic/physical } \\
\text { stress } \\
\text { Repetitive motion } \\
\text { Unsafe neighborhood / } \\
\text { housing } \\
\text { Food insecurity } \\
\text { Living in food desert } \\
\text { Inadequate nutritious } \\
\text { food choices } \\
\text { Inadequate drinking } \\
\text { water supply } \\
\text { Lack of physical } \\
\text { activity opportunities } \\
\text { Extensive debt } \\
\text { At risk of bankruptcy } \\
\text { Unable to afford: } \\
\text { Prescriptions; Medical } \\
\text { expenses; Phone; } \\
\text { Utilities; } \\
\text { Transportation; } \\
\text { Clothing; Childcare }\end{array}$ \\
\hline $\begin{array}{l}\text { Z60 Social } \\
\text { environment }\end{array}$ & $\begin{array}{l}\text { Acculturation difficulty } \\
\text { Social exclusion } \\
\text { Target of adverse } \\
\text { discrimination }\end{array}$ & $\begin{array}{l}\text { Unable to deal with } \\
\text { stress } \\
\text { Feeling unsafe in social } \\
\text { environment } \\
\text { Can hardly count on } \\
\text { family/friends } \\
\text { Inadequate social } \\
\text { interaction }\end{array}$ \\
\hline Z62 Upbringing & $\begin{array}{l}\text { Inadequate parental } \\
\text { supervision } \\
\text { Parental abuse or neglect }\end{array}$ & \\
\hline $\begin{array}{l}\text { Z63 Support } \\
\text { group / family }\end{array}$ & $\begin{array}{l}\text { Family conflict } \\
\text { Death of a family } \\
\text { member } \\
\text { Addiction in family } \\
\text { Dependent relative } \\
\text { needing care }\end{array}$ & $\begin{array}{l}\text { Chronic social/ } \\
\text { environmental stressors } \\
\text { Inadequate caregiver } \\
\text { needs } \\
\text { Providing fulltime care } \\
\text { for loved one } \\
\text { Providing hospice care } \\
\text { for loved one }\end{array}$ \\
\hline $\begin{array}{l}\text { Z64 } \\
\text { Psychosocial } \\
\text { circumstances }\end{array}$ & $\begin{array}{l}\text { Unwanted pregnancy } \\
\text { Discord with counselors }\end{array}$ & \\
\hline $\begin{array}{l}\text { Z65 Other } \\
\text { psychosocial }\end{array}$ & $\begin{array}{l}\text { Imprisonment/ } \\
\text { Incarceration } \\
\text { Conviction of crime } \\
\text { Victim of crime }\end{array}$ & $\begin{array}{l}\text { Victim of interpersonal } \\
\text { violence } \\
\text { Trauma relating to } \\
\text { refugee status }\end{array}$ \\
\hline
\end{tabular}

*Several of these are adapted from proposals at the March 5-6, 2019, ICD-10 Coordination and Maintenance Committee Meeting (pages 4546 and 21-22), ${ }^{6}$ while others are the author's own suggestions

critical first step toward acknowledging the enormous impact that social factors have on health and toward monitoring our progress in addressing these disparities. 
Corresponding Author: Zachary G. Jacobs, MD; Division of Hospital Medicine, Oregon Health \& Science University, Portland, OR, USA (e-mail: JacobsZ@OHSU.edu).

\section{Declarations:}

Conflict of Interest: Dr. Jacobs has no conflicts of interest to declare.

\section{REFERENCES}

1. US National Center for Health Statistics. ICD-10-CM Official Guidelines for Coding and Reporting FY 2021 (October 1, 2020 - September 30, 2021). Available at www.cdc.gov/nchs/icd/icd10cm.htm. Accessed December 27, 2020.

2. International Classification of Diseases (ICD) Information Sheet. World Health Organization. Available at https://www.who.int/classifications/ icd/factsheet/en/. Accessed December 27, 2020.

3. Healthy People 2030: Social Determinants of Health. U.S. Department of Health and Human Services, Office of Disease Prevention and Health Promotion. Available at https://health.gov/healthypeople/objectives-anddata/social-determinants-health. Accessed December 27, 2020.
4. Hood CM, Gennuso KP, Swain GR, Catlin BB. County health rankings: relationships between determinant factors and health outcomes. Am J Prev Med. 2016;50(2):129-135. https://doi.org/10.1016/j.amepre.2015. 08.024 .

5. American Academy of Family Physicians (AAFP). Advancing Health Equity by Addressing the Social Determinants of Health in Family Medicine (Position Paper). April 2019. Available at https://www.aafp.org/about/ policies/all/social-determinants-health-family-medicine.html. Accessed December 27, 2020.

6. ICD-10 Coordination and Maintenance Committee Meeting: Diagnosis Agenda, Part 2. March 5-6, 2019. Centers for Disease Control and Prevention. Available at https://www.cdc.gov/nchs/icd/icd10cm_maintenance.htm. Accessed December 27, 2020.

7. Center for Medicare \& Medicaid Services Office of Minority Health. Z Codes Utilization Among Medicare Fee-for-Service (FFS) Beneficiaries in 2017 Jan 2020. Data Highlight No. 18. Available at https://www.cms.gov/files/ document/cms-omh-january2020-zcode-data-highlightpdf.pdf. Accessed December 27, 2020.

Publisher's Note: Springer Nature remains neutral with regard to jurisdictional claims in published maps and institutional affiliations. 